\title{
A new species of hydrobiid snails (Mollusca, Gastropoda, Hydrobiidae) from central Greece
}

\author{
Canella Radea ${ }^{\dagger}$ \\ Department of Ecology and Systematics, Faculty of Biology, School of Sciences, National and Kapodistrian \\ University of Athens, 15784 Panepistimiopolis, Greece \\ † urn:lsid:zoobank.org:author:BBDB4903-EFD1-4B61-B07A-554D95C69BAO \\ Corresponding author: Canella Radea (kradea@biol.uoa.gr)
}

Academic editor: E. Neubert | Received 10 August 2011 | Accepted 21 September 2011 | Published 19 October 2011

urn:lsid:zoobank.org:pub:D8E8F6C9-94DA-4B09-B5E5-2F2FD09908B6

Citation: Radea C (2011) A new species of hydrobiid snails (Mollusca, Gastropoda, Hydrobiidae) from central Greece. ZooKeys 138: 53-64. doi: 10.3897/zookeys.138.1927

\begin{abstract}
A new minute valvatiform species belonging to the genus Daphniola Radoman, 1973, Daphniola eptalophos sp. n., from mountain Parnassos, Greece is described. The new species has a transparent valvatiformplanispiral shell, wide and open umbilicus, grey-black pigmented soft body and head and a black penis with a small colorless outgrowth on the left side near its base. A comparative table of shell dimensions and a key to the species known for this endemic genus for Greece are provided.
\end{abstract}

\section{Keywords}

Caenogastropoda, Hydrobiidae, Daphniola eptalophos sp. n., Greece

\section{Introduction}

Greece is a hot spot for hydrobioid gastropods both in terms of species richness and endemism (Glöer and Maassen 2009, Glöer et al. 2010). Hydrobioid gastropods include the family Hydrobiidae and several other families of Rissooidea that resemble these gastropods in general features (Hershler and Ponder 1998). To date, 72 hydrobioid species and subspecies belonging to 24 genera have been recorded in Greece (Bank 2006, 
Glöer et al. 2007; Reischütz and Reischütz 2008, Reischütz et al. 2008, Glöer and Maassen 2009, Glöer et al. 2010, Szarowska and Falniowski 2011a). It is notable that $90 \%$ of these species and subspecies and 26\% of the genera are endemic for Greece.

The hydrobiid gastropods (family Hydrobiidae) of Greece have been studied by several authors during the $19^{\text {th }}, 20^{\text {th }}$ and $21^{\text {th }}$ century (e.g., Westerlund 1886, Boettger 1892, Käufel 1930, Schütt 1980, Gittenberger 1982, Radoman 1983, Falniowski and Szarowska 2000, Bank 2006, Frogley and Preece 2007, Albrecht et al. 2009, Reischütz et al. 2010, Benke et al. 2011, Falniowski and Szarowska 2011, Szarowska and Falniowski 2011a); nevertheless, our knowledge still remains incomplete. The IUCN Red List of Threatened Species includes 42 hydrobiid species from Greece. One of them is classified as Extinct; 19 are classified as Critically Endangered, three as Endangered, one as Near Threatened, four as Vulnerable, eight as Data Deficient and the rest as Least Concern.

Daphniola Radoman, 1973 (type species Daphniola graeca Radoman, 1973) is an endemic genus from Greece. According to Schütt (1980), Daphniola graeca Radoman 1973 is a junior synonym of Valvata exigua Schmidt, 1856 and according to Reischutz and Sattman (1993) a junior synonym of Valvata (Cincinna) hellenica Westerlund, 1898.

Two of the three currently known species of this genus, namely D. exigua (A. Schmidt 1856) and D. louisi Falniowski \& Szarowska 2000 are included in the category Endangered and Critically Endangered respectively (Radea and Falniowski 2009, Radea 2011) of the Red List mentioned above. A third taxon, D. graeca was synonymized with $D$. exigua by Falniowski et al. (2007).

Recently, Falniowski and Szarowska (2011) identified a valvatiform hydrobiid gastropod found in the Peloponnisos, Greece as Horatia hadei Gittenberger, 1982, a species, which currently is listed as Islamia hadei (Gittenberger, 1982) according to Bank (2011). This gastropod was found in a distance of $40 \mathrm{~km}$ from the type locality of $H$. hadei, which probably has been destroyed (Szarowska and Falniowski 2004, Szarowska 2006). According to the above authors, the protoconch sculpture, female reproductive organs, penis morphology and a maximum likelihood phylogenetic analysis based on COI (cytochrome oxidase subunit I) fragments of mtDNA proved that this gastropod belongs to the genus Daphniola. Subsequently, Falniowski and Szarowska (2011) transferred the species hadei from Islamia to Daphniola. However, the identification of the hydrobiid gastropod found in Peloponnisos as $H$. hadei was only based on the resemblance of shell shape and protoconch sculpture and it was not supported by detailed morphological, morphometric and anatomical comparisons. Consequently, this identification as well as the new combination should be carefully re-examined.

The morphology and anatomy of the genus Daphniola have extensively been described by Radoman (1973), Radoman (1983) and Bodon et al. (2001). Morphometric variables, soft body pigmentation, male and female genitalia are widely used for the distinction of species and subspecies of this genus (Schütt 1980, Reischütz 1984, Falniowski and Szarowska 2000, Falniowski et al. 2007, Falniowski and Szarowska 2011). According to Radoman (1973), Schütt (1980), Radoman (1983), Reischütz (1984), Reischütz (1988), Falniowski and Szarowska (2000), Bodon et al. (2001), and Falniowski et al. (2007), Falniowski and Szarowska (2011) this crenobiont genus 
inhabits most of mainland Greece, i.e., Peloponnesos, Attica except its easternmost part, the western part of Euboea, southeast Thessalia and east Macedonia.

Here a new Daphniola species is described from central Greece, i.e. Sterea Ellada, and compared with its congeners.

\section{Materials and methods}

Specimens of a minute valvatoid hydrobiid gastropod from a spring nearby Agoriani (Eptalophos, mountain Parnassos, Sterea Ellada, Greece), were collected alive. Since population abundance of this species seems to be low in the spring where it was found only eighteen specimens were collected. Thirteen of them were stored in $70 \%$ ethanol for morphological and anatomical studies and five specimens in deep freezing for future molecular analyses.

Shell morphometric variables (namely shell height and width, aperture height and width) were measured of all specimens collected using the micrometer of a Stemi 2000-C, Zeiss stereomicroscope. The ratios of shell variables were calculated as well.

The structure of protoconch and teleoconch of the shells were studied using scanning electron microscopy (Jeol JSM-35 operating at $25 \mathrm{kV}$ ) after being dehydrated in a gradient of ethanol dilution series (10-100\%) and finally in pure acetone, critical point dried and spray coated in gold-palladium.

Six randomly chosen specimens were dissected (four of them were found to be mature males, one mature female and one immature female).

Shells and penes were photographed with a Canon Eos 1000D digital camera attached on a stereomicroscope Stemi 2000-C, Zeiss, Germany.

Abbreviations: ZMUA, Zoological Museum, National and Kapodistrian University of Athens.

\section{Systematics}

\section{Hydrobiidae Troschel, 1857}

Genus Daphniola Radoman, 1973

Type species Daphniola graeca Radoman, 1973

\section{Daphniola eptalophos sp. n.}

urn:lsid:zoobank.org:act:BF2C6C3F-5EF0-4375-802D-37D5529ED3E5

http://species-id.net/wiki/Daphniola_eptalophos

Figs 1-6, 7-10, 11, 14, Tabs 1, 2

Diagnosis. Shell valvatiform to planispiral; operculum circular to ovate without peg, paucispiral with subcentral nucleus; umbilicus open and very wide; male genitalia with 
a slender black penis having a colorless outgrowth located near its base; female genitalia with a well-developed bursa copulatrix and two rather small receptaculum seminis.

Description. Shell minute (Tab. 1), valvatiform to planispiral, light horn-colored to whitish, transparent, glossy, finely striated (Figs 1, 7, 9).

Protoconch microsculpture composed of a dense net of irregularly shaped pores (Fig. 8), teleoconch with fine pores among the growth lines (Fig. 10).

Spire very low and blunt; 3-3.5 convex whorls, regularly growing, divided by a moderately deep suture, last whorl strongly developed.

Umbilicus open and very wide, the earlier whorls being visible inside.

Aperture prosocline, almost circular with a sharp continuous peristome and thin margins, the upper part of columellar margin slightly leaned against to the shell wall, the outer margin simple.

Operculum (Fig. 3) ovate, dark orange, thin, thicker and more colored at the nucleus, thinner and colorless at the edges, circular to ovate with weakly convex inner face, paucispiral with subcentral nucleus without any outgrowth on inner face.

In living specimens epithelium of mantle darkly grey-black pigmented, the color being clearly visible under the transparent shell, head grey-black pigmented, large eye spots present and tentacles with a median longitudinal black stripe up to the half of their length.

Penis (Figs 4-6) black pigmented except the apex and the base, long, slender, gradually tapered towards the tip with a prolonged pointed apex, sometimes like an awl (Fig. 5), with a small unpigmented outgrowth on left side near its base (Fig. 6). Occasionally, this outgrowth is not well visible.

Bursa copulatrix ovate and well-developed, renal oviduct developed and unpigmented. Receptaculum seminis $\mathrm{rs}_{1}$ rather small, receptaculum seminis $\mathrm{rs}_{2}$ somewhat vestigial (Fig. 11).

Types. Holotype, shell height $0.90 \mathrm{~mm}$, shell width $1.50 \mathrm{~mm}$, aperture height $0.70 \mathrm{~mm}$, aperture width $0.60 \mathrm{~mm}$, collected alive (March 18, 2011), preserved in ethanol and deposited in ZMUA 4087. Paratypes 1-2, 1: shell height $1.00 \mathrm{~mm}$, shell width $1.35 \mathrm{~mm}$, aperture height $0.60 \mathrm{~mm}$, aperture width $0.60 \mathrm{~mm}, 2$ : shell height $1.10 \mathrm{~mm}$, shell width $1.40 \mathrm{~mm}$, aperture height $0.65 \mathrm{~mm}$, aperture width $0.65 \mathrm{~mm}$, collected alive (March 18, 2011), preserved in ethanol and deposited in ZMUA 4088.

Type locality. Agoriani (Eptalophos), mountain Parnassos, Sterea Ellada, Greece, $22^{\circ} 3013.5^{\prime \prime} \mathrm{N}, 38^{\circ} 35^{\prime} 35.5^{\prime \prime W}, 950 \mathrm{~m}$ a.s.l. All the specimens were found on the surface of small stones and dead leaves accumulated on the bottom of a spring covered by a thick snow layer. None other freshwater gastropod species was found to share the same spring.

Further localities. Known only from Agoriani (Eptalophos), Sterea Ellada, Greece.

Etymology. The specific name is a noun in apposition taken from the type locality. 

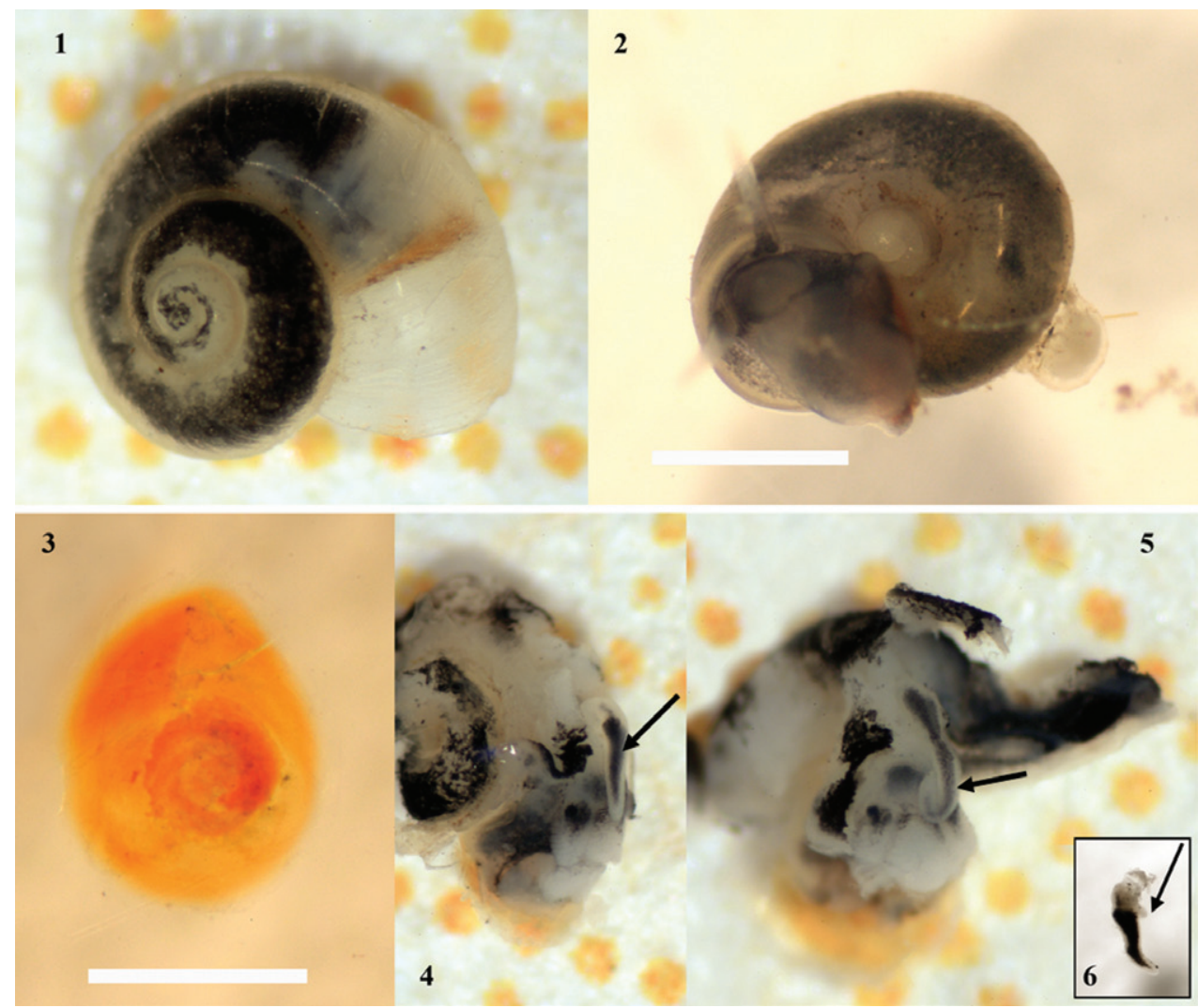

Figures I-6. D. eptalophos sp n. photographed in ethanol. Apical view I, alive specimen carrying egg capsules with an embryo on last body whorl and inside umbilicus (photographed in water) $\mathbf{2}$ operculum 3 soft body, head with tentacles and penis in situ 4-5 penis $\mathbf{6}$. A background square represents $1 \mathrm{~mm}^{2}$ in Figs 1, 4, 5. Scale bar $1 \mathrm{~mm}$ and $0.5 \mathrm{~mm}$ in Figs 2 and 3 respectively. Black arrow points the penis in Figs 4-5 and the outgrowth of penis in Fig. 6.

\section{Discussion}

The new species collected in the Parnassos Mts. belongs to the genus Daphniola because it has the characteristics of this genus as defined by Radoman (1973), Schütt (1980), Radoman (1983) and Bodon et al. (2001): 1) shell very small valvatiform 2) operculum without peg 3) penis narrow, slender and elongated with a prominent apex and one outgrowth on left side 4) female genitalia with two seminal receptacles, oviduct loop and ovate bursa copulatrix well-developed.

The macrosculpture of protoconch and teleoconch of D. eptalophos is quite similar to those described by Szarowska (2006) and Falniowski et al. (2007) for D. exigua and D. louisi respectively. 

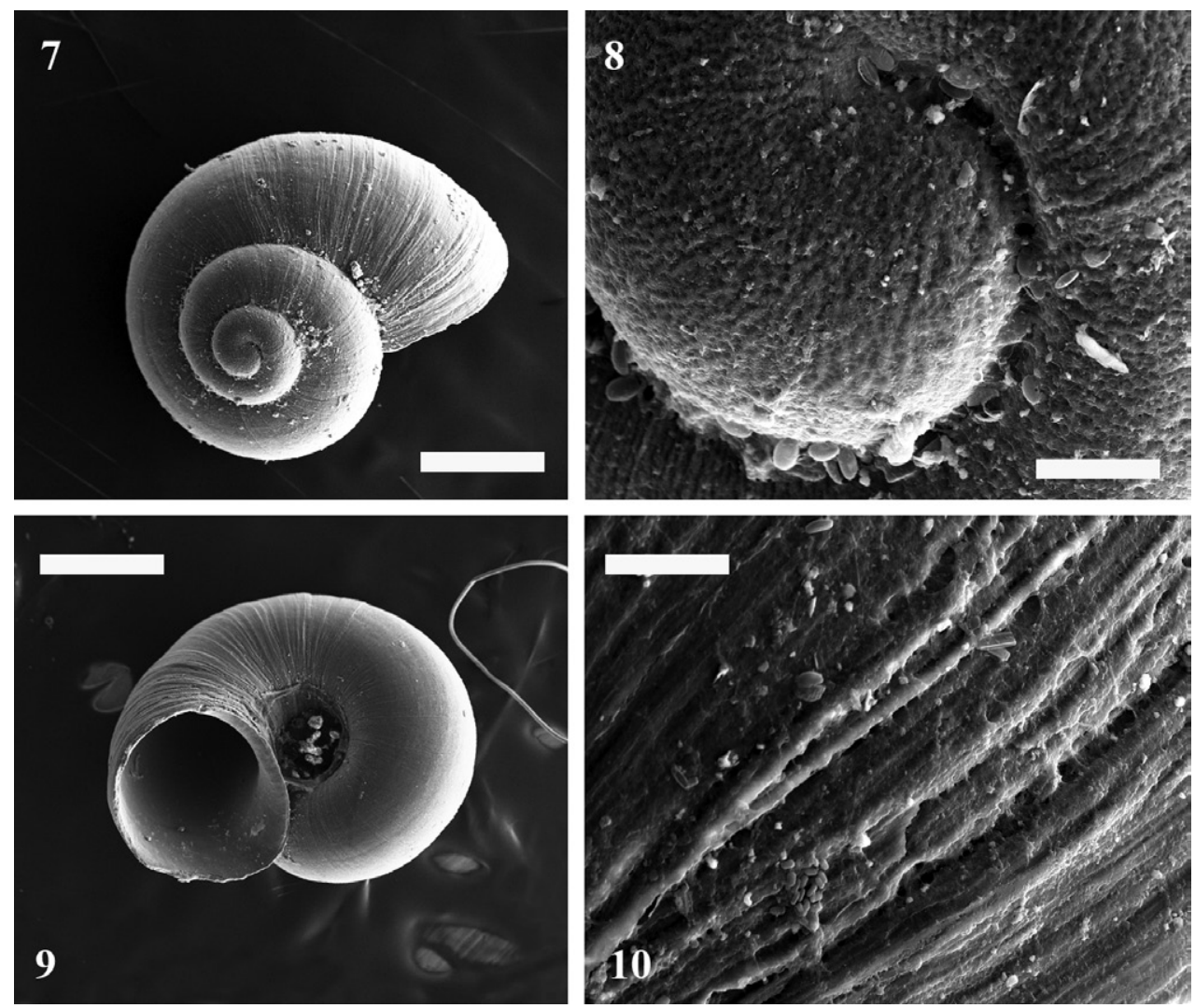

Figures 7-10. D. eptalophos sp. n. shell images from SEM Shell habitus 7, 8 protoconch 9 teleoconch 10 Scale bar $0.5 \mathrm{~mm}$ in Figs 7, 9 and $0.05 \mathrm{~mm}$ in Figs 8,10.

The shell shape of D. eptalophos resembles that of D. hadei (Figs 14-16, Falniowski and Szarowska 2011, page 133, Fig. 2-7), and its operculum resembles that of D. exigua depicted by Bodon et al. (2001: page 108, Fig. 10).

Several characteristics differentiate $D$. eptalophos from the other known species of this genus, i.e. D. exigua and D. louisi and D. hadei.

The shell of $D$. eptalophos is light horn-colored to whitish in contrast to the shell of $D$. louisi, which is brightly yellowish (Falniowski and Szarowska 2000), and of D. exigua, which is whitish to greenish-whitish (Schütt 1962).

D. eptalophos has a flatter valvatoid shell with lower spire if compared to those of D. exigua and D. louisi (Figs 14-16, Falniowski and Szarowska 2000). Additionally, the dimensions of its shell are different if compared to those of the other known species and subspecies of Daphniola (Tables 1-2).

The color of the operculum in D. eptalophos is dark orange while in D. exigua is yellowish brown (Schütt 1980) and in D. louisi light yellowish.

The umbilicus of D. eptalophos is open and wide such as the umbilicus of $D$. louisi (Falniowski \& Szarowska, 2000) and D. hadei (Falniowski and Szarowska, 2011). In 

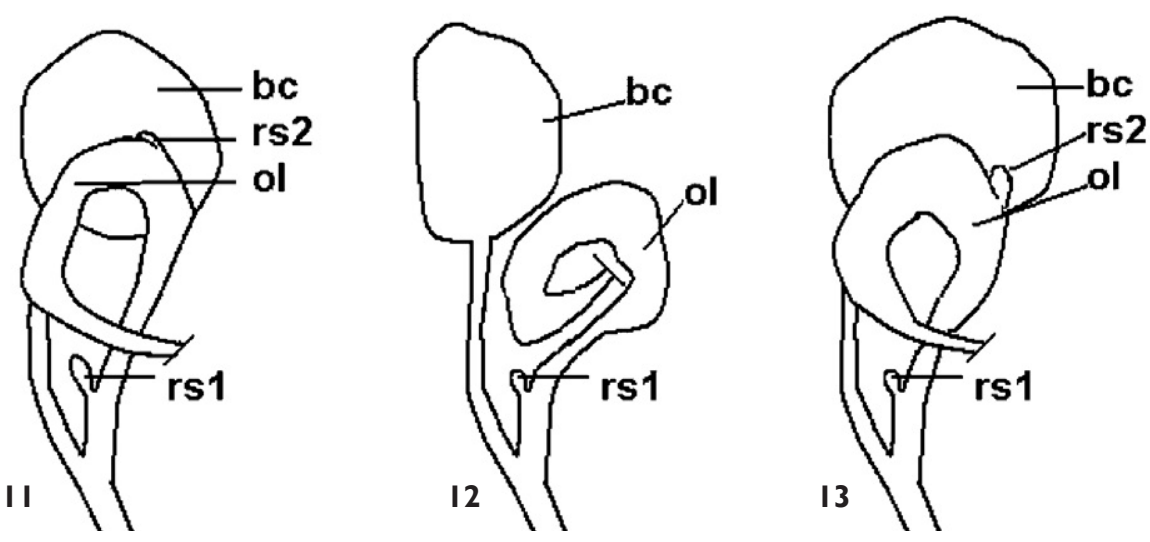

Figures II-13. Female genitalia of Daphniola species. D. eptalophos sp. n. female genitalia drawn from the only one female individual found among dissected specimens II D. louisi female genitalia re-drawn from Falniowski and Szarowska (2000) I 2 D. exigua female genitalia re-drawn from Radoman (1983) I 3 Scale bar $0.5 \mathrm{~mm}$.

contrast, the umbilicus of D. exigua is open but narrow (Schütt 1980; Reischütz 1984; Bodon et al. 2001) or semi-opened (Radoman 1973; Radoman 1983).

Body and head of D. eptalophos are dark pigmented like that of D. exigua (Falniowski et al. 2007); in D. louisi, the pigmentation of the soft parts is limited to the delicate spots on the visceral sac covering the digestive gland and gonad while the head is unpigmented (Figs 14-16, Falniowski and Szarowska 2000). The soft body of $D$. hadei is pigmentless (Falniowski and Szarowska 2011).

The eye spots of D. eptalophos are large like in D. louisi (Falniowski and Szarowska 2000), whereas the eye spot of D. hadei are rather small (Falniowski and Szarowska 2011).

The penis of D. eptalophos is more slender and elongate than that of D. louisi (Falniowski and Szarowska 2000: page 184, Figs 18-25). D. eptalophos differs from its congeners in the lateral outgrowth on the left side of penis: this outgrowth is small, rather triangular and located near its base in D. eptalophos, it is long, slender and located at half the penis length in D. exigua (Radoman 1983: page 84, Fig. 45) and it is small, blunt and located at half the penis length in D. louisi and D. hadei (Falniowski and Szarowska 2000: page 184, Figs 18-25, and Falniowski and Szarowska 2011: page 135, Figs 16-18). Finally, the penis of D. eptalophos is almost entirely black pigmented, a characteristic not observed in any other Daphniola species.

Some of the specimens collected were observed to be carrying a single hemispherical egg capsule inside the umbilicus or attached to the body whorl with an embryo at different stage of maturation (Fig. 2). The attachment of egg capsules to the shells of the same species has not been referred in literature for any other Daphniola species but it has been recorded in some other hydrobiid taxa with wide umbilicus such as Tarraconia gasulli (Boeters, 1981) and Boetersiella wolfi Boeters \& Glöer, 2007 (Ramos et al. 2000, Boeters and Glöer 2007 respectively). 

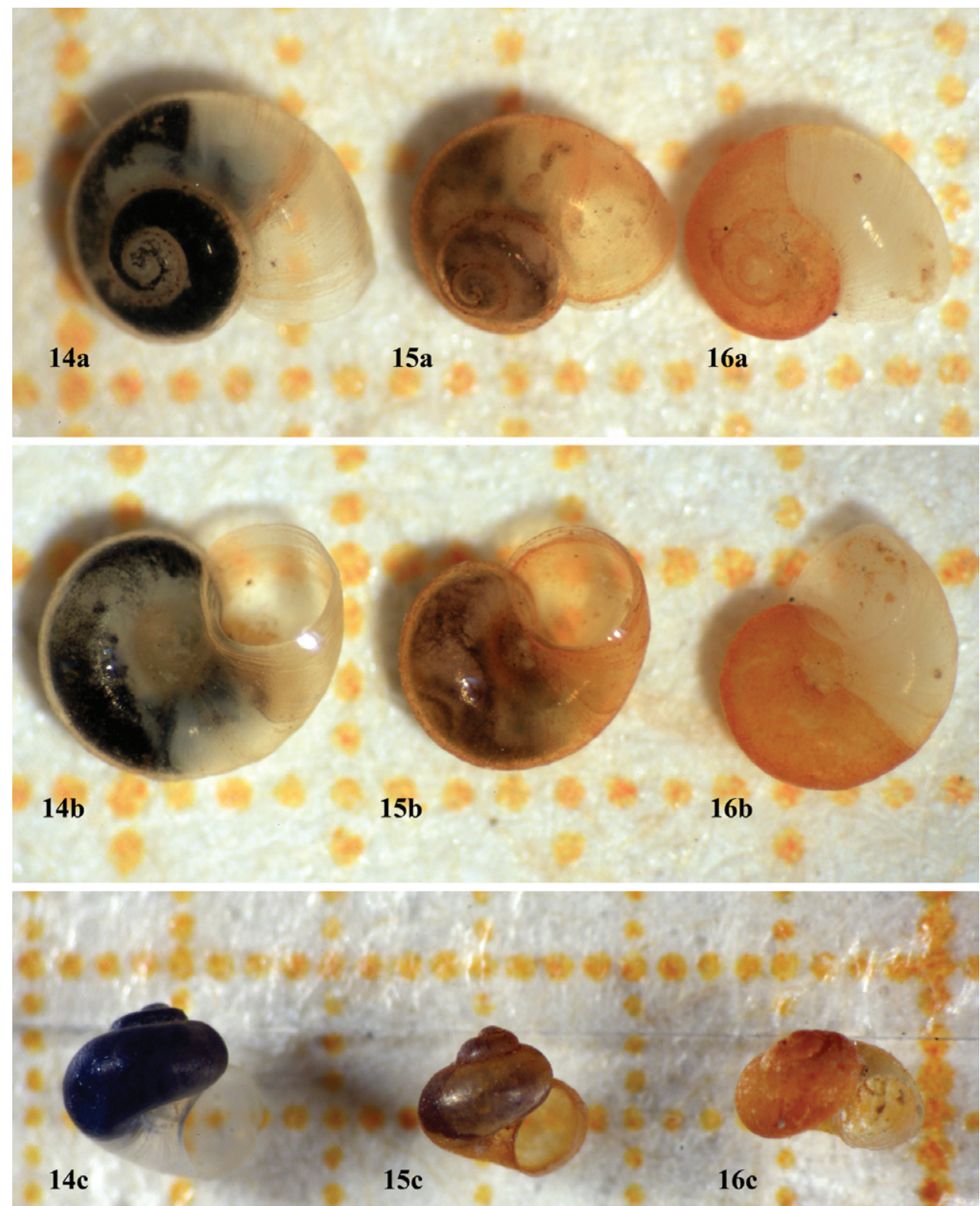

Figures 14-16. Shells of Daphniola species. a, apical view, b, ventral view, c. frontal view D. eptalophos sp. n. (Agoriani) 14 D. exigua (Marathonas, Attica) I5 D. louisi (Kessariani, Attica) 16 A background square represents $1 \mathrm{~mm}^{2}$.

To date, Daphniola eptalophos sp. $\mathrm{n}$. has been found in only one spring. This fact in combination with its low population density indicates that the new species will be highly sensitive towards any kind of change of its biotope. Obviously, a monitoring of the new species is immediately required and the assessment of its population status and trends is of high priority. 
Table I. Daphniola eptalophos sp. n. shell morphometry. Measurements in mm. Coefficient of variation $(\mathrm{CV})$ in percent $=\left(\mathrm{SD}^{*} 100 / \bar{X}\right), \bar{X}=$ mean, $\mathrm{SD}=$ standard deviation, $\mathrm{n}=$ number of specimens measured.

\begin{tabular}{c|c|c|c|c|c|c|c|c|c}
\hline \multirow{4}{*}{$\begin{array}{c}\text { D. eptalophos sp. n. } \\
\text { n=18 }\end{array}$} & & $\mathbf{s h}$ & $\mathbf{s w}$ & $\mathbf{a h}$ & $\mathbf{a w}$ & $\mathbf{s h} / \mathbf{s w}$ & $\mathbf{a h} / \mathbf{a w}$ & $\mathbf{s h} / \mathbf{a h}$ & $\mathbf{s w / a w}$ \\
\cline { 2 - 11 } & Min & 0.90 & 1.10 & 0.50 & 0.50 & 0.53 & 0.75 & 1.38 & 1.87 \\
\cline { 2 - 10 } & Max & 1.25 & 1.90 & 0.80 & 0.75 & 0.91 & 1.33 & 2.00 & 3.17 \\
\cline { 2 - 10 } & $\bar{X}$ & 1.09 & 1.46 & 0.66 & 0.65 & 0.75 & 1.03 & 1.65 & 2.28 \\
\cline { 2 - 10 } & $\mathrm{SD}$ & 0.09 & 0.21 & 0.08 & 0.07 & 0.10 & 0.13 & 0.19 & 0.34 \\
\cline { 2 - 10 } & $\mathrm{CV}$ & 8.26 & 14.38 & 12.12 & 10.77 & 13.33 & 12.62 & 11.51 & 14.91 \\
\hline
\end{tabular}

Table 2. Shell morphometry of Daphniola species. Measurements in mm.

\begin{tabular}{|c|c|c|c|c|c|}
\hline Daphniola species & & sh & sw & ah & aw \\
\hline Daphniola louisi & Min & 1.09 & 1.17 & 0.59 & 0.59 \\
\hline Falniowski and Szarowska (2000), Falniowski et al. (2007) & Max & 1.45 & 1.69 & 0.98 & 0.85 \\
\hline $\begin{array}{l}\text { Daphniola exigua } \\
\text { Schütt }(1962)^{*} \text {, Schütt }(1980){ }^{* *} \text {, Radoman }(1983)^{* * *} \text {, } \\
\text { Reischütz }(1984)^{* * * *} \text {, Falniowski et al. (2007) }\end{array}$ & $\begin{array}{l}\text { Min } \\
\text { Max }\end{array}$ & $\begin{array}{l}0.99 \\
1.58\end{array}$ & $\begin{array}{l}1.00 \\
1.40\end{array}$ & $\begin{array}{l}0.63 \\
0.87\end{array}$ & $\begin{array}{l}0.60 \\
0.87\end{array}$ \\
\hline D. hadei & Min & 0.84 & 1.14 & 0.55 & 0.52 \\
\hline Falniowski and Szarowska (2011) & Max & 0.85 & 1.15 & 0.57 & 0.54 \\
\hline D. eptalophos sp. n. & Min & 0.90 & 1.10 & 0.50 & 0.50 \\
\hline Present study & Max & 1.25 & 1.90 & 0.80 & 0.75 \\
\hline
\end{tabular}

"As Horatia (Horatia) exigua, "* as Horatia (Daphniola) exigua, ${ }^{* * *}$ as D. graeca, ${ }^{* * * *}$ as Horatia (Daphniola) exigua pangaea.

Unfortunately "hydrobioid" localities in Greece, most of them springs, are prone to changes (Szarowska and Falniowski 2004, Szarowska and Falniowski 2011b) due to urbanization, water pollution, waste accumulation, tourism and agricultural practices. Many of these localities have been destroyed, and a decline or even loss of endemic hydrobiid taxa has already been recorded (Ryan and Griffiths 2001, Szarowska and Falniowski 2004, Albrecht et al. 2006, Regnier et al. 2009, Szarowska and Falniowski 2011a).

Effective conservation measures must be urgently taken to protect "hydrobioid" localities in Greece, among them the spring nearby Agoriani, before their unique gastropod fauna disappears.

\section{Key to the Daphniola species}

1 Shell valvatiform or valvatiform to planispiral, umbilicus open and wide,

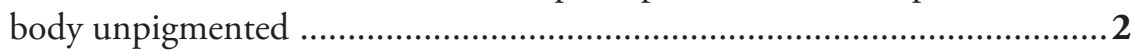

- Shell valvatiform or valvatiform to planispiral, body and head pigmented...3

2 Shell valvatiform, penis big and massive with triangular shape and a small blunt outgrowth at the middle of its length. 
- Shell valvatiform to planispiral, penis with long and narrow filament and a small blunt outgrowth at the middle of its length

D. hadei

3 Shell valvatiform, umbilicus partly covered by peristome, penis pigmentless, narrow and slender with a long outgrowth at the middle of its length

D. exigua

- Shell valvatiform to planispiral penis very dark-colored, narrow, slender with a prolonged pointed apex and a small outgrowth near its base

Daphniola eptalophos

\section{Acknowledgements}

I am grateful to Dr. K. Triantis for his helpful comments on the manuscript. I deeply thank I. Louvrou for SEM photographs and plates and P. Andriopoulos for helping on the field during material collection and with digital photographs.

\section{References}

Albrecht C, Hauffe T, Schreiber K, Trajanovski S, Wilke T (2009) Mollusc biodiversity and endemism in the putative ancient Lake Trichonis (Greece). Malacologia 51: 357-375. doi: 10.4002/040.051.0209

Albrecht C, Lohfink D, Schultheiss R (2006) Dramatic decline and loss of mollusc diversity in long-lived lakes in Greece. Tentacle 14: 11-13.

Bank RA (2006) Towards a catalogue and bibliography of the freshwater Mollusca of Greece. Heldia 6: 51-86.

Bank RA (2011) Fauna Europaea: Mollusca, Gastropoda. Fauna Europaea. Version 2.4, http:// www.faunaeur.org [accessed 17.IX.2011]

Benke M, Brändle M, Albrecht Ch, Wilke Th (2011) Patterns of freshwater biodiversity in Europe: lessons from the spring snail genus Bythinella. Journal of Biogeography doi: $10.1111 /$ j.1365-2699.2011.02527.x

Bodon M, Manganelli G, Giusti F (2001) A survey of the European valvatiform hydrobiid genera, with special reference to Hauffenia Pollonera, 1898 (Gastropoda: Hydrobiidae). Malacologia 43: 103-215.

Boeters HD, Glöer P (2007) A contribution to the genus Boetersiella Arconada \& Ramos 2001 in Spain with the description of Boetersiella wolfi n.sp. Heldia 5: 85-88.

Boettger O (1892) Schnecken von der Insel Giura, N. Sporaden, aus dem phokischen Parnass und aus anderen griechischen Gebieten. Nachrichtsblatt der Deutschen Malakozoologischen Gesellschaft 24: 59-66.

Falniowski A, Szarowska M (2000) A new species of Daphniola Radoman 1973 (Gastropoda: Hydrobiidae) from Greece. Folia Malacologica 8(3): 181-188. 
Falniowski A, Szarowska M, Grzmil P (2007) Daphniola Radoman, 1973 (Gastropoda: Hydrobiidae): shell biometry, mtDNA, and the Pliocene flooding. Journal of Natural History 41: 2301-2311. doi: 10.1080/00222930701630733

Falniowski A, Szarowska M (2011) Radiation and phylogeography in a spring snail Bythinella (Mollusca: Gastropoda: Rissoidea) in continental Greece. Annales Zoologici Fennici 48: 67-90.

Falniowski A, Szarowska M (2011) The genus Daphniola Radoman, 1973 (Caenogastropoda: Hydrobiidae) in the Peloponesse, Greece. Folia Malacologica 19(3): 131-137. doi: 10.2478/v10125-011-0020-9

Frogley MR, Preece RC (2007) A review of the aquatic mollusca from Lake Pamvotis, Ioannina, an ancient lake in NW Greece. Journal of Conchology 39: 271-295.

Gittenberger E (1982) Eine neue Horatia Art aus Griechenland (Prosobranchia, Hydrobiidae). Basteria 46: 68.

Glöer P, Albrecht Ch, Wilke Th (2007). Enigmatic distribution patterns of the Bithyniidae in the Balkan Region (Gastropoda: Rissooidea). Mollusca 25(1): 13-22.

Glöer P, Maassen WJM (2009) Three new species of the family Bithyniidae from Greece (Gastropoda: Bithyniidae). Mollusca 27: 41-48.

Glöer P, Falniowski A, Pešič V (2010) The Bithyniidae of Greece (Gastropoda: Bithyniidae). Journal of Conchology 40: 179-187.

Hershler R, Ponder WF (1998) A review of morphological characters of hydrobioid snails. Smithsonian Contributions to Zoology 600: 1-55. doi: 10.5479/si.00810282.600

Käufel F (1930) Die schalentragenden Land- und Süßwassermollusken. In: Beier M (Ed) Zoologische Forschungsreise nach den Jonischen Inseln und dem Peloponnes. Sitzungsberichte der Mathematisch-Naturwissenschaftlichen Classe der Kaiserlichen Akademie der Wissenschaften, Wien Abt. 139: 160-188.

Radea C (2010) Daphniola exigua. In: IUCN 2011. IUCN Red List of Threatened Species. Version 2011.1. www.iucnredlist.org [accessed 10.VII. 2011]

Radea C, Falniowski A (2009) Daphniola louisi. In: IUCN 2011. IUCN Red List of Threatened Species. Version 2011.1. www.iucnredlist.org [accessed 10.VII. 2011]

Radoman P (1973) New classification of fresh and brackish water Prosobranchia from the Balkans and Asia Minor. Prirodnjacki Muzej u Beogradu 32: 1-30.

Radoman P (1973) Hydrobioidea a superfamily of Prosobranchia (Gastropoda). I. Sistematics. Monographs, Serbian Academy of Sciences and Arts 547, Department Sciences 57, Beograde, 173 pp.

Ramos MA, Arconada B, Rolan E, Moreno D (2000) A new genus and a new species of hydrobiid snail (Mollusca: Gastropoda: Hydrobiidae) from eastern Spain. Malacologia 42(1-2): 75-101.

Regnier C, Fontaine B, Bouchet P (2009) Not knowing, Not recording, Not Listing: Numerous unrecognized Mollusc Extinctions. Conservation Biology 23: 1214-1221. doi: 10.1111/j.1523-1739.2009.01245.x

Reischütz P (1984) Zur Kenntnis von Horatia (Daphniola) exigua (A. Schmidt 1856) (Gastropoda, Prosobranchia, Hydrobioidea). Malakologische Abhandlungen 10: 17-18. 
Reischütz PL (1988) Beiträge zur Molluskenfauna Thrakiens und Ostmakedoniens, II. Annalen des Naturhistorischen Museums in Wien 90B: 341-356.

Reischütz P, Sattmann H (1993) Beitrage zur Nomenklatur der europaischen Binnenmollusken, V. Die Taxa der Hydrobioidea des griechischen Festlands mit valvatoidem Gehäuse und Festlegung eines Lectotypus von Valvata (Cincinna) hellenica Westerlund 1898 (Gastropoda: Prosobranchia). Heldia 2(1/2): 51-52.

Reischütz A, Reischütz PL (2008) Hellenika pantoia 20: Hauffenia hadei molai nov. subspec. aus Lakonien (Peloponnes, Griechenland) (Gastropoda: Prosobranchia: Hydrobiidae). Nachrichtenblatt der Ersten Vorarlberger Malakologischen Gesellschaft 15: 29-30.

Reischütz A, Reischütz P, Fischer W (2008) Hellenica pantoia 22: Zur Verbreitung der Gattung Bythinella Moquin-Tandon 1856 (Gastropoda: Prosobranchia: Hydrobiidae) auf der Peloponnes (Griechenland). Nachrichtenblatt der Ersten Vorarlberger Malakologischen Gesellschaft 15: 35-36.

Reischütz A, Reischütz N, Reischütz PL (2010) Hellenika pantoia 28: Die Molluskenfauna des Pamissos (Peloponnes: Griechenland). Nachrichtenblatt der Ersten Vorarlberger Malakologischen Gesellschaft 17: 33-35.

Ryan S, Griffiths HI (2001) The decline and probable extinction of Graecoanatolica macedonica (Gastropoda: Orientalinidae) in Balkan Lake Dorjan. Journal of Conchology 37: 261-265.

Schütt H (1962) Neue Süsswasser-Prosobranchier Griechenlands. Archiv für Molluskenkunde 91: 157-166.

Schütt H (1980) Zur Kenntnis griechischer Hydrobiiden. Archiv für Molluskenkunde 110: $115-149$.

Szarowska M (2006) Molecular phylogeny, systematics and morphological character evolution in the Balkan Rissooidea (Caenogastropoda). Folia Malacologica 14: 99-168.

Szarowska M, Falniowski A (2004) "Hydrobioid" localities in Greece: An urgent case for conservation. Tentacle 12: 14-15. doi: 10.1080/00222933.2011.591067

Szarowska M , Falniowski A (2011a) An unusual, flagellum-bearing hydrobiid snail (Gastropoda: Rissooidea: Hydrobiidae) from Greece, with descriptions of a new genus and a new species. Journal of Natural History 45(35-36): 2231-2246. doi: 10.2478/v10125-0110010-y

Szarowska M, Falniowski A (2011b) Destroyed and threatened localities of rissoid snails (Gastropoda: Rissoidea) in Greece. Folia Malacologica 19: 35-39.

Westerlund CA (1886) Fauna der in der paläarctischen Region (Europa, Kaukasien, Sibirien, Turan, Persien, Kurdistan, Armenien, Mesopotamien, Kleinasien, Syrien, Arabien, Egypten, Tripolis, Tunesien, Algerien und Marocco) lebenden Binnenconchylien. VI. Fam. Ampullaridae, Paludinidae, Hydrobiidae, Melanidae, Valvatidae \& Neritidae, Lund, 156 pp. 